\title{
Industrial Relations, Migration, and \\ Neoliberal Politics: The Case of the \\ European Construction Sector
}

\author{
NATHAN LILLIE \\ University of Helsinki \\ AND \\ IAN GREER \\ Leeds University
}

Transnational politics and labor markets are undermining national industrial relations systems in Europe. This article examines the construction industry, where the internationalization of the labor market has gone especially far. To test hypotheses about differences between "national systems," the authors examine the United Kingdom, Finland, and Germany, alongside European-level policy making. Regardless of overall national institutional framework, employers seek to avoid industrial relations rules, while unions attempt to relocalize labor relations. Both use shop-floor, national, and European power resources. The authors argue that comparative industrial relations should take seriously the connection between action at the national and transnational levels.

Keywords: $\quad$ trade unions; varieties of capitalism; migration; European Union;

Construction

The authors would like to thank the interviewees. We are grateful to lan Fitzgerald and Jan Cremers for help with the research process. Thanks to Miguel Martinez Lucio and the School of Management at Bradford University and to Michael Fichter and the Otto Suhr Institute at the Free University of Berlin for providing facilities for fieldwork. Thanks to the editorial board of Politics \& Society for their comments on the manuscript and to Markku Sippola for research assistance. Finally, thanks to the participants in the workshops “Political Economy of Immigration and Migrant Labour," March 10-11, 2006, in London and “The Unprotected Migrant: Mobility, Social Policy and Labour Rights in Europe," May 16-17, 2006, in Tampere, Finland, and the WERD seminar in Leeds in January 2006. Funding for this research was provided by the Helsinki Collegium for Advanced Studies, a University of Helsinki Project Research Grant, the German Academic Exchange Service, and the Hans Boeckler Foundation.

Transnational labor markets, production, and capital movement play increasingly important roles in industrial relations. In some industries, there is evidence of employment systems diverging within national contexts, while at the same time converging internationally. ${ }^{1}$ Nonetheless, many scholars continue to assign overriding influence to national institutions on shaping the interactions of unions and employers ${ }^{2}$ and treat transnational political arenas as apolitical and exogenous to policy making, downplaying the neoliberal reorientation of elites. This article will show that while national 
institutions have not disappeared, industrial relations actors now operate in a trans- and supranational environment, where rules are in flux and enforcement far from self-evident. Supranational politics, transnational production, and transnational labor markets are supplanting and undermining national institutions as influences on employer and union strategy.

To demonstrate the interplay between trans- and supranational politics and national industrial relations, we look at construction in three European Union (EU) member countries: Finland, Germany, and the United Kingdom. Although construction is traditionally a very local industry, worker migration and EU politics now play a crucial role. As employers increasingly seek "exit" from regulated sectoral industrial relations systems, union capacities for autonomous action, independent of national institutional relationships, assume greater importance.

Much of the debate on the internationalization of the economy and industrial relations has focused on manufacturing and the increasing tendency of employers to shift production or to threaten to shift production to cheaper locations. ${ }^{3}$ In construction, a "race to the bottom" would work differently, since most work must be done on the site itself, regardless of the price of local labor. Instead of moving abroad, construction employers seek to bring cheap labor from abroad into high-wage countries. With migrant labor recruited locally or transnationally, large contractors gain a reservoir of workers whose expectations are oriented to conditions in their country of origin rather than the host country where the work is performed. Subcontracting and worker "posting" (i.e., firms sending employees from one country to work in another) used together enable employers to protect themselves from legal liability, while isolating migrants from the economic and social norms of the host society. Regulation of worker posting is tied up with the national and EU politics of industry-specific regulations (e.g., skill, health and safety, and technical standards), social policy, eastern accession, and the freedom of movement of services and persons. This multilevel game increasingly shapes the constraints and opportunities for unions and employers.

Construction employers, with the aid of the Commission of the EU, and acquiescence of national governments, have made it an integral part of their strategy to access opportunities outside the national state framework. In each of our country cases, construction employers are using migrant labor to push the industry toward a "low-road" model of weaker collective bargaining and worker representation; their ability to do this, however, depends on domestic labor market conditions and union capacities for relocalizing labor market regulation. Employer organizations and indeed many construction firms occupy an ambiguous position in this development. Although, as Georg Menz notes, employer organizations continue to influence national policy responses to Europeanization, ${ }^{4}$ we find that both employer and government responses are half-hearted, inconsistent, and in the end, dependent on external enforcement by unions for their effectiveness. As capital abandons national institutions, in reality if not always in rhetoric, labor unions are increasingly left to their own devices. Our country cases show that the most effective union responses in a neoliberal environment are those which, in the first instance, rely on autonomous union capacities ${ }^{5}$ rather than on institutionalized relations with the state and employers to control the labor market.

We assess how well the unions in our country cases have retained control over the labor market with reference 
to wage developments, considering also the amount of work taking place inside the regulated framework and whether wage developments result from union influence or market forces. In Finland, the union continues to exert control over the labor market by conducting secondary boycotts in defense of the sectoral collective agreement. Despite pressures from increased worker posting, wages have grown steadily in step with the rest of the economy, and the amount of work outside the regulated framework remains small. In Germany, stagnating wages, concession bargaining, and a large shadow economy reflect union weakness, despite innovative strategies and good institutional access. In the United Kingdom, rapid wage gains have occurred in the context of a building boom despite union weakness rather than because of it. Unions and workers are willing, on occasion, to engage in militant autonomous action, but the resulting union successes have been limited in scope and duration.

Below, we discuss our methods and case selection. We then contrast the institutional literature with our own approach. Next, we describe the politics of construction labor mobility at the European level and in Finland, Germany, and the United Kingdom. Finally, we draw on evidence from EU politics and our three country cases to critique institutional theory.

\section{MULTILEVEL RESEARCH DESIGN AND OVERVIEW OF CASES}

This article is based on material gathered from interviews in Brussels, Germany, Finland, and the United Kingdom. We chose our country cases, not just because they have different institutions of labor participation and traditions of trade unionism, but also because they have a common affiliation with the EU and are host to migrant construction workers. We conduct a matched comparison of a single phenomenon-the expansion of migrant labor, facilitated by employer strategies and the growth of the European single market as well as union responses - across a range of contexts. This allows us to isolate the effect of national systems on actor strategies and bargaining outcomes, bracketing issues of industry structure, and to nest local and national variation within the broader context of European-level regulation. The case studies are based on interviews with trade unionists and industry representatives at the European, national, and local levels, press reports on specific disputes, union newsletters, and where available, secondary academic literature.

Migrants account for a substantial share of the construction workforce in Europe. Estimates in Finland vary between 10,000 and 15,000 or $10-15$ percent of the national construction workforce. The majority of construction migrants from Estonia work in the Helsinki region. ${ }^{6}$ In Germany, the best estimate puts the legally posted workforce at 16 percent in construction; this does not include undocumented or foreign-born resident workers. ${ }^{7}$ In Britain, the government does not include the self-employed in its count of migrant workers and therefore undercounts construction. Trade unionists and employer association representatives we interviewed estimated the share of migrants in construction at 10 percent.

Germany and Finland both have one dominant union in construction (IG BAU and Rakennusliitto, respectively), ${ }^{8}$ whereas British construction workers are divided among an industry union (UCATT) and three general unions (GMB, Amicus, and TGWU). ${ }^{9}$ Rakennusliitto bargains within a framework of national- level corporatist income policies; its membership density (at between 70 and 80 percent) is bolstered by a Ghent-style social insurance system. ${ }^{10}$ Employers 
are represented by an industry association, Rakennusteollisuus, whose members include almost all large construction employers in Finland. Members and nonmembers alike are bound by legally extended collective agreement. IG BAU operates within Germany's dual system of industrial relations, with two national- level bargaining partners on the employer side, whose members are legally bound to following collective agreements and account for a substantial portion of the legal domestic construction industry (80 percent of firms in the West, 33 percent in the East). Employer association membership and union density (at 20 percent) are similar to overall German figures. ${ }^{11}$ In the United Kingdom, unions have little national strategy and depend largely on on-site activity, especially when it comes to representing migrants. Unionsespecially shop stewards - use more militant rhetoric than their Finnish or German counterparts but are constrained by Thatcher-era legal restrictions, a fragmented structure, and low membership density (around 16 percent, compared to the economy-wide figure of nearly 30 percent). ${ }^{12}$ The Construction Confederation, the United Kingdom's major employer association, claims membership controlling about 70 percent of the industry's turnover. Its members, who tend to be large contractors, are expected to adhere to its collective agreements, which it claims cover about 75 percent of the industry. ${ }^{13}$

\section{VARIETIES OF UNIONISM OR UNIONS INA NEOLIBERAL WORLD?}

The creation of a pan-European and transnational construction labor market and the emergence of supranational regulatory politics have created problems for nationally focused mainstream institutional theory. Traditional institutional theory characterizes industrial relations actors as embedded in interlocking sets of self-reinforcing rules confined to national spaces. Our critique is not simply a preference for one level of analysis over the other. Rather, we contend that trans- and supranational dynamics are important for development at the national level. Internationalization creates problems for traditional institutional analysis, because transnational production and supranational politics create overlapping environments and rule systems, which allow capital to strategically evade and undermine localized regulatory frameworks. In such a situation, the focus of analytical emphasis needs to shift from norms and institutions to actors and strategies.

In contrast to Menz, who reasserts the importance of national varieties of capitalism by showing how Europeanization is "mediated" through national institutions, ${ }^{14}$ we do not see national response strategies so much as we see union and employer response strategies. For institutions to "matter" in the sense meant by varieties of capitalism theorists, they must have independent effects beyond simply reflecting the immediate distribution of power between labor and capital. A multilevel, comparative, actor-centered research strategy helps us move beyond the 1990s institutionalist dichotomy between national politics as sites for social regulation and transnational politics as sites for market making ${ }^{15}$ and to challenge assumptions about union and employer behavior based on obsolete typologies.

Cross-border labor mobility is nothing new. What is new is that it forms part of a deliberate and strategic deregulatory project and is implemented in ways that undermine national labor regulation. During the post-World War II economic expansion in Western Europe, employers recruited millions of immigrants to cope with a labor shortage. This earlier generation of immigrants led a relatively settled existence in industrial towns, mainly paid according to the bottom rungs of collective bargaining agreements (CBAs). By contrast, employers today use migration, with or without labor 
shortages, to undermine collective bargaining and employment regulation. Posting, in particular, allows firms to control the international movements of workers and keep them separate from other workers, giving them a special, precarious status. $^{16}$

These employer strategies have implications for the political economy of labor. The self-reinforcing sets of national institutions emphasized by institutionalists have lost the coherence needed to self-reinforce. These systems once relied on acceptance by opposing actors of certain ground rules and, indeed, of each other. ${ }^{17}$ Now, however, the transnational context provides firms with more exit options, allowing them to contest or escape from these rules and avoid worker representation altogether.

Orthodox institutional analysis views employers as nationally based, situated within institutional structures that encourage them to choose from a range of predictable strategies. Faced with globalization, the theory predicts that employers will not necessarily seek to deregulate labor relations and reduce union power but rather to reinforce their national basis of competitiveness. This means maintaining one of two models: that of a coordinated market economy (CME) or a liberal market economy (LME). Change is incremental, path dependent, and tends to converge around two points of equilibrium corresponding to this typology. ${ }^{18}$ In this logic, Finnish and German employers should have as much an interest in maintaining strong nonmarket regulation as British employers have in preserving market-based regulation.

In institutional analysis, German industrial relations have been a paradigmmaking case of both stability and change. The increasingly obvious distance between the stability predicted by varieties of capitalism and the reality of the collapsing German system has compelled some institutionalists to focus on the latter. Thelen and van Wijnbergen, for example, show the ways in which national institutions mediate "exogenous" market pressures for change along nationally specific trajectories. ${ }^{19}$ Although more dynamic, this model remains nationally bounded, with drivers for change located outside the political realm or at least outside the influence of trade unions. Streeck and Thelen write, "liberalization ... can often proceed without political mobilization, simply by encouraging or tolerating self-interested subversion of collective institutions from below, or by unleashing individual interests and the subversive intelligence of self-interested actors bent on maximizing their utilities."20 Here, the process of deconstructing national systems appears as an increasingly constrained set of undesirable choices for unions, derived from an apolitical process of market making. Meanwhile, developments in new trans- and supranational political arenas go unnoticed, and their consequences appear as done deals, that is, as constraints that domestic actors must simply accept or be punished by market forces.

Menz deploys a more sophisticated analysis of EU policy, but even here, the emphasis is on how national configurations of interest affect the way EU member states respond to integration pressures. He recognizes deregulation as a political project, but it still appears as exogenous pressure-generated in the EU and resisted by national employer associations and unions alike (often in concert). ${ }^{21}$ We, however, see labor transnationalism on the shop floor as integrally connected to supranationalism in Brussels. Actors are not creating some sort of national labor or capital interest, which then mediates Brussels' politics into their insular national environment. Rather, national actors act in their own fragmented interests within a multilevel environment shot through with transnational firms, labor markets, and 
increasingly, worker solidarity. Comparative institutionalist scholars looking at union revitalization use a similar logic to varieties of capitalism, although with an added emphasis on agency. This "varieties of unionism" approach takes national institutional structure as important, though not "determinative," with the other important variable being internal union dynamics. ${ }^{22}$ While we do not dismiss the importance of organizational and national factors, there are two points on which our evidence contradicts the revitalization approach. First, these scholars argue that unions in CMEs will be more "embedded" in institutional frameworks than those in LMEs and therefore less likely to innovate. ${ }^{23}$ In our German case, innovation arose from desperation, and Finnish unions have also devised new strategies and retargeted old ones with great success. Second, like other institutionalist paradigms, "varieties of unionism" continues with a nationally bounded analysis, so that, although agency is recognized, critically important new arenas of political struggle remain outside the paradigm. In construction, transnational labor markets arise from a conjunction of deregulatory EU politics and transnational firm-level subcontracting relations, which nationally rooted unions and employers seek to influence. In contrast to comparative institutionalists, we see the rescaling of political conflict as integral to industrial relations actor strategies. ${ }^{24}$

Restructuring, deregulation, and new forms of labor migration reshape the familiar spaces of political contestation in which unions and employers act. Geographically, this can mean an upscaling or downscaling of strategy or structure to campaign, lobby, or build markets in local, transnational, or supranational contexts. ${ }^{25}$ In the context of the "retreat of the state," national-level institutional levers no longer provide the power resources they once did. ${ }^{26}$ Union and employer strategies are directly connected to power resources and bargaining leverage. This is an open-ended process involving workplace, national and transnational layers, rather than the nationally bounded process involving mutually reinforcing institutions, norms, and strategies favored by institutional schools.

\section{RATCHETING UP COMPETITION: EU LEGISLATION AND LABOR MOBILITY}

The EU is a discrete political space where the balance of political power between labor and capital is different from that of any specific national context. In the EU, actors can outflank national-level political constraints by opening up a different political terrain. EU legislation compels national governments to adopt certain policies, with limited flexibility about how to transpose directives into national legislation. From its outset, the EU has been a market-building project. The Commission and the European Court of Justice have used the EU's mandate to remove barriers to trade expansively, in ways that not only enable transnational trade and investment in the $\mathrm{EU}^{27}$ but which also promote neoliberal policies more generally. Market-making regulation is generating conflict between neoliberal advocates of free movement of services and people and actors who want to preserve national standards. 
Table 1

Institutional versus Actor-centered Approaches to Labor Movements

\begin{tabular}{ccc}
\hline Basic Cause of Change & $\begin{array}{c}\text { Employer Strategies and Path- } \\
\text { dependent Institutional Change }\end{array}$ & $\begin{array}{c}\text { Power Relations in Politics } \\
\text { and the Market }\end{array}$ \\
\hline $\begin{array}{c}\text { Actor strategies structured } \\
\text { by . . . }\end{array}$ & $\begin{array}{c}\text { frameworks of enforceable } \\
\text { rules. }\end{array}$ & $\begin{array}{c}\text { frameworks of power and } \\
\text { opportunity. } \\
\text { susceptible to economic pressures } \\
\text { and changes in power } \\
\text { relations. }\end{array}$ \\
$\begin{array}{c}\text { Employer strategies mainly } \\
\text { constrained by ... }\end{array}$ & $\begin{array}{c}\text { nationally specific rules } \\
\text { consistent with "institutional and nationally } \\
\text { advantage." }\end{array}$ & $\begin{array}{c}\text { industrial conflict (mainly } \\
\text { domestic) and markets } \\
\text { (domestic and transnational). }\end{array}$ \\
$\begin{array}{c}\text { Employer "exit option" } \\
\text { portrayed as ... }\end{array}$ & $\begin{array}{c}\text { disinvestment from high-wage } \\
\text { countries. }\end{array}$ & $\begin{array}{c}\text { creation of low-wage, regulation } \\
\text { free zones domestically or } \\
\text { transnationally. }\end{array}$ \\
Key divergences are .... & mainly between countries. & $\begin{array}{c}\text { inseparable between and within } \\
\text { country processes. }\end{array}$ \\
\hline
\end{tabular}

Key institutions in the European legislative process are the European Commission, a supranational executive and bureaucracy, the intergovernmental Council of Ministers, and the supranational European Parliament (EP). This decisionmaking structure encourages actors to formulate interests along transnational lines. Directives also allow for important differences in national implementation, so national-level politics remain important in EU policies. ${ }^{28}$ Although the Council of Ministers and EP can veto or modify legislation, the Commission is in many ways more influential, because it alone can initiate legislation. During the 1990s, there was a shift in the Commission's policy goals away from a Social Democratic "Citizens' Europe" of regulated capitalism backed by the Commission's president, Jacque Delors, and toward a neoliberal model of market making and deregulation. ${ }^{29}$ Emphasis has moved to the Internal Market Directorate General (DG), which grants multinational firms and business associations-but not unions- early access in crafting legislation. ${ }^{30}$ Since much of this legislation appears designed to undermine pro-labor EU directives, member state regulation, and collective agreements, unions have reverted to opposing legislation in the EP through lobbying, street protests, and strikes. ${ }^{31}$

Labor mobility is one of the "Four Freedoms" of the EU enshrined by the Treaty of Rome and pursued by the European Commission. Trade unions do not usually oppose increased mobility in Europe per se but do oppose specific changes to the regulation of mobility that undermine national social protection and union power resources. The EU politics of labor mobility in construction have revolved around the passing and implementing of the 1996 Posted Workers Directive, the 2004 accession of Eastern European and Mediterranean island countries to the EU, ${ }^{32}$ and the debate over the 2006 Services Directive. Each of these issues has involved important interactions between firm-level union and employer practices, national politics, and EU politics. Employer practices such as transnational subcontracting shape the political agendas of unions and employers in EU-level regulation. At the same time, political events at the EU level (such as Eastern accession) have created opportunities for new employer practices and new challenges for trade unions.

In the early 1990s, the EU became a major site for reregulatory activity, as unionists and industry representatives worked together to frame EU-level regulations to govern the working standards of "posted" workers in the construction industry. Because of a construction boom in the newly acceded East German Lander, posted workers from Western Europe 
appeared in increasing numbers on German construction sites. The German social partners, with the help of their representatives in Brussels, lobbied for an EU directive establishing the host country principle. In 1996, the EU passed the Posted Workers Directive, establishing that posted construction workers are entitled to the statutory minimum conditions of either their host state or sending state, whichever is better from the worker's perspective; in other words, it allows national regulation over construction (and other sectors, if a national government so chooses) without imposing an EUwide standard. ${ }^{33}$ Thus, the directive has more impact in countries with minimum wages and legally extended collective agreements, whereas maintenance of national regulation by other means, such as public sector tendering rules, remained prob- lematic. ${ }^{34}$ The Posted Workers Directive initially had little impact because of a decline in the importance of posting in the late $1990 \mathrm{~s},{ }^{35}$ but in the context of increasing labor migration from Eastern Europe, the directive has become more important in reshaping the national- and site-level regulatory terrain in construction.

The migration issue came to the forefront again in 2004 with the accession of ten new countries into the EU. In most Western European countries, temporary transition periods were intended to cushion the impact of Eastern accession, ${ }^{36}$ and in Germany, where unions face high unemployment and firms' high insolvency rates, the delay could extend up to seven years. In Finland, unions decided that the transition period was encouraging posting, making it harder to monitor working conditions of migrants, and with their support, the transition period ended in May 2006. The United Kingdom opened its labor market immediately to Eastern European workers. As with the Posted Workers Directive, EU policy over accession enabled national-level regulations on labor mobility within specified constraints. In response to increasing migration from the east, the Finnish and German unions adjusted their strategies to take advantage of the Posted Workers Directive. This consisted of enforcement of national standards in very different ways, as we will discuss in the national case narratives.

Meanwhile, business interests responded to national reregulatory pressures by working with the Commission's Internal Market DG to draft a directive on the free movement of services in the EU, establishing a "country of origin" principle for regulating service-sector firms, including building contractors. The proposed Services Directive presented by the Commission became highly controversial because it threatened to undermine national regulation, including regulation sanctioned by EU legislation and European Court of Justice (ECJ) jurisprudence. ${ }^{37}$ The directive's advocates maintained that the inclusion of a country of origin principle would have merely amounted to the implementation of the (already constitutionally established) freedom to provide services. Inclusion of the principle in the directive would have provided clarity by restricting governments (and perhaps unions as well ${ }^{38}$ ) from regulating services in ways deemed to restrict trade, effectively extending the EU's mutual recognition principle, established by the ECJ in the well-known Cassis de Dijon case for trade in goods, to the services sector. ${ }^{39}$ The directive's critics, however, argued it would lead to a chaotic clash of national laws and jurisdictional confusion and create a race to the bottom in social standards. Like "flags of convenience" in maritime shipping, transnational corporations could set up "letterbox" subsidiaries to operate Europe-wide under whichever set of national rules they preferred. ${ }^{40}$ The directive threatened to make national rules very difficult to enforce.

The politics around the Services Directive and country of origin principle were about much more than just industrial relations, so the motives surrounding the various positions actors took were not solely shaped by labor issues. 
However, unions and employers could not escape the implications that a broadly interpreted country of origin principle would have had for employment relations. As a result, the directive became caught up in and in a certain sense held hostage by the conflict between the EU's founding principles and the rights of workers and unions to take collective action in defense of their interests. National unions and employer groups became very much involved in Services Directive politics, acting on all levels to educate their members, to lobby their governments, and to work through their Brusselsbased associations in the European Parliament. ${ }^{41}$

According to representatives of the Federation de I'Industrie Europeenne de la Construction (FIEC), the construction industry's main representative body in Brussels, the push for the Services Directive came not from the construction industry but from technocrats within the EU Commission and large service transnational corporations outside construction. The multisectoral employer group, Union of Industrial and Employers' Confederations of Europe (UNICE), lobbied for the "country of origin" principle against the wishes of the construction lobby, which would have preferred an exemption for its industry. ${ }^{42}$ FIEC, however, had an ambivalent stand toward the directive: they joined unions in criticizing it but did not oppose it. ${ }^{43}$ Although many European building contractors would have suffered from the inclusion of a country of origin principle, others would have benefited. Large, multinational general contractors could have reduced their costs by using subcontractors applying country of origin terms and conditions. Also, the directive promised to eliminate subtle forms of discrimination against internationally operating contractors in tendering procedures and licensing rules. On the other hand, the country of origin principle would have harmed small- and medium-sized contractors in high-wage countries that continued to abide by local labor standards. ${ }^{44}$ Within the employers' camp, there were conflicts of interest between low-wage and high-wage countries and-within the high-wage camp- between large general contractors and small specialty subcontractors.

Because of union mobilization and lobbying and concerns expressed by parts of the business community, the EP and Council amended the directive significantly. ${ }^{45}$ The text finally passed in November 2006 does not include the country of origin principle. As a result, the directive's effects will probably be less dramatic than originally envisioned by the Commission. It is possible that the European Court of Justice will eventually rule that the country of origin principle is the practical application of an established right and therefore does not need legislative support from the Services Directive. However, this is unlikely, given that the EU's legislative bodies have now passed legislation specifying exactly what the freedom of movement of services means-and it does not mean the country of origin principle.

The Services Directive battle represents a clear union victory, albeit a defensive one. Elements of the European Commission and transnational capital regard the country of origin principle as an idea whose time has come, and there will likely be more efforts to introduce it by other means. Nevertheless, the high stakes of the Services Directive battle have served as a wake-up call for unionists on the threat posed by neoliberal policies emanating from Brussels. As one Finnish trade unionist told us, "We do our best to protect our members, but the EU can at any time drop a bomb . . . anything can come from there, and workers and unions can do very little to affect it." ${ }^{\prime 6}$ Employers and unions have become alert to the implications of European politics for construction regulation and will continue to be involved at all levels as new European initiatives emerge in the future. 


\section{FINLAND}

The effect of migrants on Finland's construction labor market is limited by the strength and resources of Finnish unions. Rakennusliitto monitors employer practices closely and uses industrial action, including secondary boycotts, to force main contractors to compel their subcontractors to comply with laws and CBAs. Although the government inspects work sites and inspectors penalize employers who do not follow labor laws and collective agreements, the Finnish construction labor market is primarily regulated through direct union action.

Overall, labor immigration into Finland is a new and limited phenomenon. Unlike in Germany and the United Kingdom, migrants have until recently had little presence in the Finnish labor market, partly due to immigration restrictions and partly due to job discrimination by employers. ${ }^{47}$ In construction, however, the recent trend to worker posting from the Baltic States has resulted in numbers of migrants proportionally comparable to those in Germany and the United Kingdom. Revelations of poor labor practices among subcontractors have become common in the Finnish media, with regular reports on illegally low pay, poor living and working conditions, and other abuses. ${ }^{48}$

Rakennusliitto upholds wage standards despite the presence of nonunion posted workers by enforcing the legally extended collective agreements over the entire construction workforce. It does so mainly through industrial action against noncompliant firms. Finland's wage bargaining system consists of a framework set by a multisectoral corporatist income policy agreement implemented through sectoral agreements, which in most industries are made legally binding over the sector by government decree. ${ }^{49}$ Posted worker regulations cover all industries and require foreign building contractors to pay industry CBA rates. ${ }^{50}$ Secondary boycotts are a well-established Finnish trade union practice but have been specifically adapted to relocalize labor relations by taking advantage of the framework created by the Posted Workers Directive.

Rakennusliitto cooperates closely with authorities and believes that work inspectors and police focus on punishing the employers of undocumented workers rather than the workers themselves. ${ }^{51}$ Recently, the work inspectorate has expanded to include nine new inspectors specialized in migrant workers, and a new law has come into effect as part of a deal for ending the transition period on labor mobility, allowing inspectors to fine general contractors for violations by subcontractors. Fines fall short of full liability, however, and in themselves are not seen as sufficient to prevent main contractors from using disreputable subcontractors. ${ }^{52}$ Both unions and employers are skeptical that the state can control illegal work, and Rakennusliitto uses the law as justification for its own, more effective pressure tactics against legally sanctioned companies..$^{53}$

For Rakennusliitto, boycotts are the most important power resource. The majority of boycotted firms are foreign subcontractors, but their customers are main contractors, whose names are readily recognizable in Finland: Skanska, YIT, and PEAB, for example. ${ }^{54}$ In 2005, Rakennusliitto announced thirty-eight boycotts on its Web site, twenty-one of which involved subcontractors with identifiably foreign names; in 2006, forty-three boycotts were announced, thirty- three of those being against firms with Estonian names. In these cases, union members were asked not to work for the boycotted firm. Although ostensibly organized to deny labor to the subcontractor, boycotts really work by pressuring the main contractor. Main contractors end their ties with boycotted firms because of worries about solidarity strikes and their own 
reputation. ${ }^{55}$

Employers do not approve of Rakennusliitto enforcing standards through boycotts. ${ }^{56}$ They see enforcement as the appropriate role of the police and work inspectorate, although they readily admit that these organizations do not have the resources for comprehensive monitoring. ${ }^{57}$ Restricting boycotts through national legislation does not seem likely in the short term, however, ${ }^{58}$ and some Nordic employers have sought to shift scale to the European level as a way around this. In two current cases, Laval and Viking, the European Court of Justice is considering the legality of boycotts. The Viking case involves a Finnish ferry company boycotted by the Finnish Seamen's Union, and the Laval case, a Latvian construction subcontractor boycotted by the Swedish construction union. The employers in both cases contend that national industrial relations rules permitting secondary strikes against foreign employers are a barrier to free movement of services in contravention of EU law. ${ }^{59}$ While a decision against the unions could impose severe restrictions on boycotts, ${ }^{60}$ simultaneous preliminary advisory rulings by ECJ Advocates General issued in June 2007 favored the continued right of unions to use industrial action in defense of national standards. ${ }^{61}$

Rakennusliitto monitors employers through a network of firm-level shop stewards and site-level "health and safety men." It also sends officials to sites to check on conditions by examining paperwork and talking to the workers. Union officials emphasize the importance of strong site-level networks across all the contractors in the monitoring and enforcement of standards. ${ }^{62}$ Because most difficulties in irregular employment circumstances arise with subcontractors, multifirm, site-level union structures allow the union to keep track of subcontractors where there are less likely to be shop stewards. At the association and upper management level, employers are increasingly making efforts to avoid boycotts by not dealing with subcontractors known to work illegally; however, many contractors have come to rely on the cheapness and flexibility of subcontractors using posted workers despite the risks.

Because it can preserve wage standards without actually mobilizing migrants, Rakennusliitto does little to mobilize or recruit migrants. The Helsinki metropolitan area office of Rakennusliitto has hired a Russian- and Estonian-speaking officer, but his job is workplace monitoring rather than member recruitment. In 2004, the Suomen Ammatiliittojen Keskusjarjestus (SAK or the Finnish Central Organization of Trade Unions) opened an information office in Estonia to assist job seekers going to Finland, with information on their employment rights in Finland. Infopoint staff do not directly seek to recruit but rather to help workers distinguish legitimate opportunities from fraudulent and exploitive situations and in doing so, project a positive image of the Finnish labor movement and strengthen ties with Estonian colleagues. ${ }^{63}$ Despite the SAK's investment in this project and the printing of recruitment and information materials in Russian, Estonian, and English, the number of migrant workers in Finnish unions remains small.

The construction of the Olkiluoto 3 nuclear power plant near the town of Rauma on the west coast may be a sign of upcoming challenges for Finnish construction unions. The main contracts went to foreign firms that, through extensive subcontracting to non-Finnish firms, have attempted to avoid the Finnish unions and regulatory system by shifting scale to the EU level. TVO, the Finnish electrical utility, is coordinating the project, with the German Siemens AG, and French Framatome ANP as main contractors and over 900 subcontractors from twenty-six countries. As of autumn 2007, the site 
will employ more than 2,500 workers, around 80 percent of whom are foreign. ${ }^{64}$ Workers come from twenty- six different countries, ${ }^{65}$ with the largest foreign groups being French, German, and Polish. ${ }^{66}$

The Finnish construction employers' association, Rakennusteollisuus, and Rakennusliitto politically supported construction of the plant on the assumption that Finnish employers and employees would benefit, but both are very displeased with the outcome. The union had assumed the high demand for workers in a sparsely populated region would push wages up. Instead of attracting Finnish workers to the region with above CBA salaries, foreign subcontractors have posted their foreign workforce, putting downward pressure on wages and making industrial relations contentious. ${ }^{67}$ Initially, in October 2005, when contractors tried to deny union representatives access, citing security concerns, Rakennusliitto and the transport workers union threatened a boycott to gain access. ${ }^{68}$ Union recruitment has been difficult, with an estimated 10 percent of posted workers now having taken membership. One problem has been the rotation of workers every six months, which the companies do to avoid paying taxes. Union officials, however, believe that their efforts have been a learning process, and they will be able to organize and monitor the site better in the future. ${ }^{69}$

Despite the proximity of the Baltic States and Russia, migrant workers have not overwhelmed the labor market. This is not due as much to national employer strategies for high quality, as the Olkiluoto case shows, as it is to the tight control of Rakennusliitto's local- and national-level boycotting strategies. The availability of migrants happy to work for collective agreement rates may have reduced site-level upward wage drift, but the amount of work taking place outside the regulated framework remains small. Although Olkiluoto shows that the internationalization of contracting can pose a challenge to Rakennusliitto's otherwise solid control over the domestic labor market, it remains to be seen if this really is the thin end of a wedge. Because of the Laval and Viking preliminary opinions and the compromise over the Services Directive, it seems that the EU is likely to tolerate the union's labor market controls for the foreseeable future.

\section{GERMANY}

In Germany, the construction workers union, IG BAU, has not been able to cope with the influx of posted workers. As a result, wages have stagnated, union membership has declined, and a large proportion of construction work occurs outside the regulated framework. As Marcus Kahmann points out, IG BAU's responses to the crisis have relied primarily on corporatist political tools rather than autonomous union action. ${ }^{70}$ IG BAU, sometimes with the cooperation of employer groups, has supported government inspections, main contractor liability, a long "transition period" on freedom of movement from Eastern Europe, and in some states, social standards in public contracting. Unlike the Finnish union and U.K. unions, IG BAU does not have the tradition of shop- floor mobilization or the site-level structures to enforce its collective agreements on a day-to-day basis. Works councils are the usual means by which German unions access the shop floor, but these are based around firms rather than job sites and do not necessarily exist in smaller firms. With increased subcontracting, works councils are more and more a phenomenon of the main contractor firms only. As a result, despite the widespread discontent among members and an arguably successful nationwide strike in 2002, IG BAU has relied primarily on the courts, relations with employers, and government inspections to enforce standards on construction sites.

Germany is well known for its guest workers program of the postwar boom era. Unlike Finland, which staffed its 
expanding industries with internal migrants from the countryside, Germany recruited workers from Turkey, the Arab world, and Southern Europe for hundreds of thousands of mainly unskilled and semiskilled factory and construction jobs. After unification, Germany experienced an influx of posted construction workers, as it rebuilt the infrastructure that had decayed because of the division of the country. Workers came from around the EU, mainly from the United Kingdom and Portugal and, often illegally, from countries to the east. As the expected revival of unified Germany's economy did not materialize, the construction industry collapsed. Employment fell from 1.5 million in 1995 to 740,000 in 2003, and IG BAU's membership declined from 780,000 just after unification to below 400,000 in 2006, despite an influx of 100,000 members from a merger. Unemployment and insolvency rates climbed, and the "shadow economy" became a major topic of public discussion. ${ }^{71}$

According to IG BAU officials and activists who work with migrants, large numbers of migrant workers come from the former Yugoslavia, Poland, and the Czech Republic, as well as worse-paid groups from Romania and the Ukraine. Unlike the guest workers of the past, many are "commuters," who rotate in and out of Germany and from site to site rather than settling in a single place. They are usually paid according to the statutory minimum wage for the sector, or (illegally) wages close to what they would receive in their home countries rather than according to the CBA. Of special significance is the growth of under-the-table work, either by unemployed Germans or undocumented migrant workers; employers estimate that 35 percent of revenue in construction is generated by the underground economy, ${ }^{72}$ and IG BAU has estimated the number of workers in the unregulated sector at between 300,000 and 500,000. ${ }^{73}$ Given 118,000 posted workers out of 603,000 total blue-collar workers, a nearly 50 percent decline in the sector's employment from the mid-1990s, and a rapid decline in union membership, the sector's social partners face severe challenges. IG BAU has had to make much deeper concessions than other German unions.

Migrant construction workers in Germany face the same problems seen elsewhere: employers promise reasonable wages but take deductions for transportation, housing, and food, leaving workers with less take-home pay than they expected. Workers are employed at the bottom of convoluted contracting chains of Strohmanner, shell firms that exploit the gap between hourly all-in rates and basic pay rates by winning contracts and subcontracting the work further and pocketing a percentage of the money that would otherwise go for wages, insurance, social security contributions, or taxes. Subcontractors sometimes disappear, leaving wages and statutory contributions unpaid. Articles in the tabloids sometimes feature IG BAU officials, churches, and other activists providing shelter and legal representation for stranded workers who have been employed under scandalous conditions.

IG BAU's response has several components that can work at cross-purposes but all of which seek to relocalize labor regulation in the context of a labor market transnationalized through unregulated subcontracting. Chief among them is working with the government. During the 1990s, in reaction to an influx of posting through Portuguese and British contractors, the unions and employers' associations helped establish Germany's minimum wage so that the Posted Workers Directive would have an impact. These rates, however, were below the level of the CBA, allowing main contractors to legally use subcontractors paying below the agreement. IG BAU has also worked with the employers' association to win nominal statutory extension of collective agreements, albeit with uneven cooperation from contractors. 
With mixed success, the union lobbied for regulation in the public works contracting chain. A few Lander, but not the federal government, have passed Tariftreugesetze, which are laws stipulating that contractors on public projects must abide by collective agreements.

IG BAU's cooperation with authorities has become the subject of heated debate, both within the union and involving outside migrant rights advocates. Fighting the shadow economy was an important policy initiative of the RedGreen government. Under recent legislation, the Hauptzollamt, the agency responsible for collecting taxes, set up a special unit known as the Finanzkontrolle Schwarzarbeit, employing 5,000 former agents from the unemployment offices and the border control to police the workplace. IG BAU recruited its own members to go to construction sites and spot illegal work and established a tip line that allows callers to anonymously report suspected illegal work. The arguments against IG BAU's involvement with government enforcement are first, that it stokes feelings of xenophobia among union members, and second, the union should show solidarity by supporting migrant workers rather than helping to monitor (and possibly deport) them. There is also a quieter and less principled argument: many works councillors at large firms fear stringent enforcement of employment rules in the contracting chain, because it imposes risks for their employers, who need cheap subcontractors to reduce their costs and win contracts.

Employers have played a curious role in monitoring illegal work: although rhetorically, they advocate enforcement of standards, in concrete terms, their support has barely gone beyond making joint statements with local union officials. Some local associations have even refused to cooperate, despite their official function to regulate wages in the sector. Much of this reluctance stems from the widespread fears that getting caught for "unserious" practices could hurt the associations' members by tarnishing their reputation. While one way to avoid being caught would be to comply with the law, there is also an alternative strategy of undermining enforcement, which has the advantage that it does not raise costs in the contracting chain.

Main contractor liability, institutionalized in Germany's posted worker law, has been an especially tricky issue for employers' associations. As with the Finnish main contractor law, the German law holds main contractors responsible for monitoring the practices of their subcontractors. The German law goes much further, however, in holding main contractors liable for the unpaid wages and social security contributions of their subcontractors, while the Finnish law only imposes a set fine. The Hauptverband der deutschen Bauindustrie, representing larger firms, claims that this imposes enormous burdens on main contractors, who are responsible for checking compliance with four different social insurance funds. Unscrupulous subcontractors, they argue, can use this law to conspire with their workforces to force double payment from main contractors: first, payment to the subcontractor for services rendered and second, if the firm disappears, payment to the workers and insurance funds for back wages and contributions. ${ }^{77}$ Main contractor liability is likely to remain in place, however, because it is supported by IG BAU, small contractors, and, above all, the social insurance funds. If anything, the law will be tightened to ease enforcement.

With employers facing insolvency and low-wage competition and the union helpless to enforce rules and wage norms through strikes over immediate workplace issues, it has become increasingly clear that without drastic action, IG 
BAU has no way to stop the downward spiral of concessions and membership decline. Union officials in four different regions expressed the view, without our asking, that IG BAU's national structure is outmoded, and that a construction union would function better at the European level. As a result, IG BAU has attempted an ambitious project to shift the scale of unionism to the European level by founding the European Migrant Workers' Union (EMWU).

The founding aspiration of the EMWU was to operate throughout Europe in all sectors where migrants work, including several where IG BAU is present: construction, building cleaning, and agriculture. The union has invested 1.5 million euros in this project. It has hired Polish speakers to work with migrant construction workers in Germany and set up an office in Warsaw to maintain contact with members and pursue claims against main contractors. Rather than a competitor union or a rigidly separate organization, the EMWU works closely with IG BAU offices that come into contact with migrants. The most common problem is wage fraud by subcontractors; the EMWU and IG BAU use negotiations to expedite wage payments from main contractors and avoid lengthy, complex, and expensive court battles. IG BAU had hoped that EMWU would attract 10,000 members in its first year, but membership levels have not come close to this. EMWU's main accomplishment in its first two years has been to bring Polish speakers into union work, providing a crucial resource for IG BAU officials seeking to help migrants in wage-fraud cases. Although EMWU enjoys solid political support within IG BAU, unions in other countries have yet to embrace it. Without adequate dues income or support from other national unions, EMWU remains dependent on financial support from IG BAU.

The decline of union power can be seen most clearly in the union's bargaining policies. One survey of firm-level pacts in Germany's one hundred largest firms in various industries found that the most substantial concessions and layoffs were occurring in construction. ${ }^{78}$ This included the high-profile case of Phillip Holzmann, which, like thousands of smaller construction firms, went bankrupt during the collapse of the late 1990s. The extent of job losses from bankruptcy is not clear, since portions of bankrupt firms now operate as small enterprises under new ownership. Nevertheless, the wave of bankruptcies led to massive changes in sectoral bargaining, despite the success of the 2002 strike. In 2003, IG BAU agreed to an unprecedented unconditional opening clause allowing the reduction of holiday pay at the firm level; in 2006, to a working time increase without pay compensation; and in 2007, to a pay increase largely contingent on firm-level negotiations.

Although IG BAU has been the most ambitious in promoting labor transnationalism and has an impressive array of initiatives with the state and employers to protect the domestic construction industry, these strategies have not reversed union decline. IG BAU played a central role in European-level fights over the Posted Workers and Services directives and has had the vision to invest in creating an actual transnational union, whose members commute across boundaries. Although EMWU has won some members, it has not spread to other countries or provided the membership gains that its founders had hoped for. Efforts at the national level to reregulate through cooperation between labor, industry, and government have been insufficient, partly because of controversy within the union over working with the authorities, partly because large firms need low-cost subcontractors to compete (and works councillors accept this), and partly because of a consensus among leaders in industry and the government that market-based regulation is ultimately the most efficient. 


\section{THE UNITED KINGDOM}

In the United Kingdom, construction workers have seen rapid wage gains due to tight labor markets, and as a result, collective bargaining has made substantial advances. Unions are not really controlling the labor market as much as harnessing it, although they have had success in dealing with other issues, such as health and safety, and in fighting the abusive practices that have emerged as a result of increased worker posting. Like their Finnish counterparts, British unions have a tradition of shop-floor action, although they do not have the resources or legal rights to use strikes systematically as a tool to control the labor market. British unions try to deal with migrants the same way they do with native workers, without a special organization such as the EMWU. Important in their strategies are new skill standards and registration schemes, tightening up the abuse of notional selfemployment, and enforcing the EU working time rules for the selfemployed. ${ }^{79}$

For decades, high unemployment in construction made the United Kingdom a major labor supplier in Europe. Since 2000, however, the United Kingdom has experienced a building boom, and the government predicts severe shortages of skilled craft workers in construction because of major urban redevelopment projects in London and a wave of public works and housing construction else- where. ${ }^{80}$ The labor shortage has led to efforts by firms and the government to attract migrant workers as well as massive wage gains. While the boom has brought big pay increases, it has not benefited British unions in terms of membership. The expansion of the sector and stable union membership figures have combined to bring union density from 26 percent in 1995 down to 16 percent in 2005. Immigration status and posting have been less problematic in the United Kingdom than in Germany or Finland, because workers from the new EU member states gained access to the labor market immediately in 2003.

In some ways, the problems faced by migrants in Britain are similar to those seen elsewhere in Europe. Migrants are often paid less than promised, after (sometimes illegal) deductions from paychecks for travel, housing, and food. The stories that make it into the media, such as the 2003 case of Indian stonemasons building a Sikh mosque in Bedford for less than a pound an hour, are noteworthy but arouse less indignation than the stream of cases seen in the German and Finnish press. ${ }^{81}$ In some ways, migrants are under less pressure in the United Kingdom, because of the ease of obtaining legal employment as "free" agents on the labor market-in Germany, more migrants work illegally, and in Finland, more migrants are posted workers. Despite difficulties, migrants have some flexibility to take advantage of the tight labor market and to exercise their rights as union members.

British unionists consciously avoid association with the immigration authorities, partly because they do not view it in their interest to be associated with authorities that deport people, partly because of the labor and skills shortage, and partly because of a lack of interest from the government. Union attempts to lobby government to impose standards have focused on public works projects. These initiatives depend on devolution; outside of London, Wales, and Scotland, where

regional governments have significant power, authorities must contend with Thatcher-era competitive tendering legislation banning the imposition of social requirements on contractors. However, in regions that have embraced devolution (which all have Labour-led governments), unions have turned to subnational government to impose social 
regulation on publicly funded projects. In the construction of a new Terminal 5 at Heathrow Airport, regulations imposed by the contracting authority restricted use of self-employed labor, ensured compliance with national collective agreements in the supply chain, and helped unions expand their role on the site. ${ }^{82}$ The unions have also been working with the mayor of London to frame regulations for Olympics-related construction in East London, based on the model of the Heathrow project.

Union officials seem to view brief, unsanctioned work stoppages as a more effective means to win small battles on job sites than state intervention. ${ }^{83}$ The United Kingdom's culture of spontaneous work stoppages shapes how unions target migrant workers. At an industrial site in Cottam, Lincolnshire, for example, a small group of English welders and scaffolders went on a five-week strike in solidarity with a Hungarian colleague who was laid off after attending a union meeting. Together with Amicus and GMB full-time officials, they organized weekly demonstrations outside the gates that attracted hundreds of union activists from throughout the country. The owner of the power station forced the contractor to settle the dispute, and the final compromise included paying the migrants according to the British collective agreement. Complications continued, as workers reported that the Hungarian subsidiary of the company was not paying them properly; with the support of the project owner, labor and management agreed to a monitoring procedure to assure that the proper wages were transferred into the workers' Austrian and Hungarian bank accounts. ${ }^{84}$ Despite the solidarity shown by British colleagues, when the project ended, most of the posted workers left the country and lost touch with British unions.

Although a rare example of British construction union engagement with migrants, Cottam is not entirely unique. In 2005, the Trades Unions Congress (TUC), the United Kingdom's trade union umbrella organization, together with UCATT and Northumbria University, conducted an action research project to address the needs of migrant workers. ${ }^{85}$ In northeast England, union officials have been organizing Polish workers mainly on small housing projects. UCATT targeted one of the larger employers of Polish workers for paying bricklayers around half of the local market rate. Much of the action on the construction site was spontaneous, such as a stoppage that occurred in response to the sacking of a worker. Furthermore, the union put pressure on the employer to raise wages by pointing the workers toward better-paying jobs available in the tight labor market. UCATT has attempted to build contacts within the community of Polish construction workers, not only by recruiting members but also by organizing a meeting at the local Polish club, together with a staffer seconded from the Polish union Solidarity. While migrants appear to be a small proportion of the local labor force (less than 1,000 out of 100,000 workers in the northeast), some officials view organizing as a way to prevent main contractors from pushing down prices generally, which would force well-organized subcontractors to reduce their wages as well. Within UCATT, however, political support for migrant organizing seems to rest on short-term membership developments; migrant organizing, therefore, may not have a future at UCATT.

The degree of regulation varies substantially between regions. In the north, the industry is much better organized, with lower levels of immigration and much higher union membership than the southeast. London, by contrast, resembles the chaotic situation faced by IG BAU, albeit with a severe labor shortage. The building boom has attracted a workforce from around Europe, either posted by international contractors, brought by recruiting firms, or recruited locally on street 
corners or through social networks. Some of the major contractors have established subsidiaries that recruit workers from lower wage areas elsewhere in Europe. Community organizations with union ties exist in two of the largest migrant communities, the Portuguese and Polish; a Portuguese workers' organization was for some time housed in the TUC's regional headquarters in London. The Federation of Poles in Britain, the umbrella organization of Polish organizations in the United Kingdom, has worked with the TUC to help individual construction workers pursue claims in industrial tribunals but lacks ties to individual construction unions and has no affiliate or officer dedicated to employment issues. ${ }^{86}$

Because southeast England faces acute shortages of skilled labor, most employers of migrant construction workers seem to pay according to or above the CBA. In some cases, however, such as a well-publicized Hindu temple case in West London, employers pay below the agreement and indeed, below the statutory minimum wage. In this case, the contractor had recruited stone masons in India. UCATT took the case to an employment tribunal and won nearly $f 100,000$ worth of back pay from the contractor under the provisions of the statutory minimum wage, including more than $£ 31,434$ for one activist. $^{87}$

British construction unionists, in comparison to their French and German colleagues, tend to act more in reaction to specific membership demands and abuses arising from posting than out of a strategy for relocalizing labor market controls and are also less involved in international work. Unlike IG BAU, they lack a sense of crisis, and compared to Rakennusliitto, they are more fragmented and lacking in rights and membership density. They have discussed participating in the EMWU and decided against it, reasoning that a separate organization could open the door for separate collective agreements and exclude migrant workers from existing union structures. ${ }^{88}$ British unions take a grassroots workplacecentered approach to organizing migrants that depends more on initiative from workers on-site than an overarching national strategy implemented by full-time officials. Since their main levers are employment tribunals, the domestic labor shortage, public contracting in regions with devolved government, and the sporadic willingness of workers to walk off the job, the rapid wage gains made in recent years have not been caused by this union strategy.

Table 2 summarizes key facts about our country cases. 


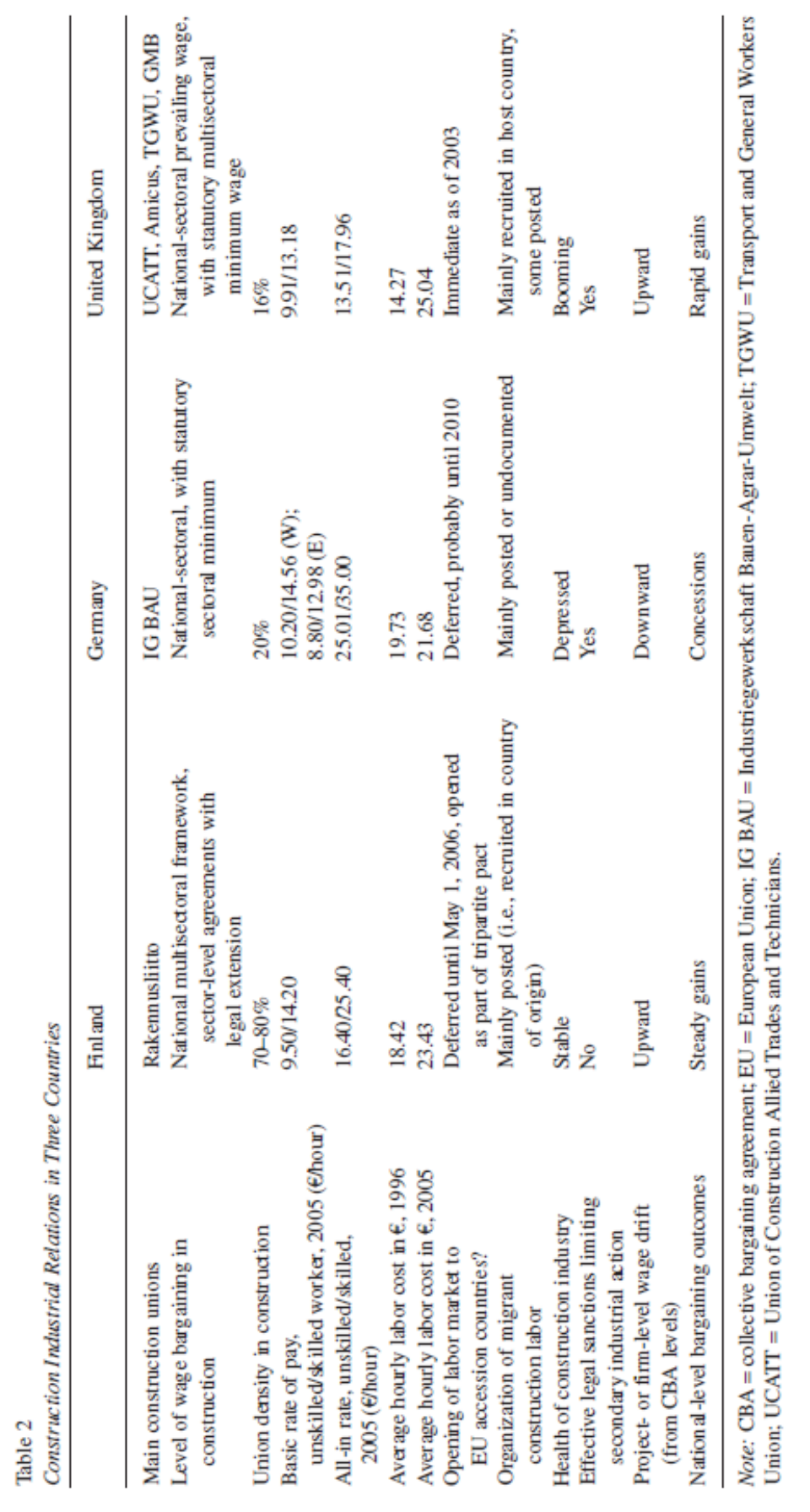




\section{UNIONS, LIBERALIZATION, AND MIGRATION}

Employers and unions have shifted scales to operate in a multilevel political terrain characterized by transnational labor mobility and shifting opportunities for influence. For unions in all of our country cases, their ultimate goal is to enforce nationally agreed collective norms, even if their transnationaland European-level strategies are an increasingly important part of this strategy. In addition to political lobbying within EU institutions, unions have numerous tactics for relocalizing labor relations: secondary boycotts, primary industrial action, regulatory enforcement, standard setting in public contracting, bilateral linkages with unions in labor supply countries, and migrant organizing.

Variations arise from differences in national systems (legal restrictions, political opportunities, and other power resources), but these changes do not correspond readily with categories such as CMEs and LMEs. Restrictions on industrial action cut across the varieties of capitalism, with both British and German unionists facing restrictions that undermine their abilities to uphold standards on the work site. The decisive difference between British and German construction unions over the past ten years has been the economic boom in the former country, compared to mass unemployment in the latter. In Finland, it is the mobilization capacity of construction union and not national employer strategy that allows the union to maintain control over the labor market. The major United Kingdom employer association is not significantly less sympathetic to regulation than the ones in our CME cases and seems mainly concerned with preserving industrial peace. ${ }^{89}$ Even in our best organized case, Finland, employers 
look for openings, and only the constant vigilance of a strong and militant union has kept collective bargaining intact. This comparison suggests that whatever the level of action, autonomous mobilization capacities at the shop floor are essential for viable union strategy: governments and employers lack either the capacity or a consistent interest in maintaining standards and as a result, do not make reliable partners.

While it would be possible to speak of "hybrid models" or "path dependence," it seems more productive to show the problems the Europeanization of the construction industry raise for institutional theory. One problem is that employer behavior is not what the institutionalist narrative predicts it should be.

Employers in all three countries seek on various levels to circumvent labor standards through subcontracting and worker posting, and they intervene politically to facilitate this circumvention. Employer views on national regulation can be directly read off from the success or failure of union relocalization strategy: as the Finnish case shows, when unions have sufficient leverage to force employers to remain within national systems, they do-although employers complain about unions using these levers. When unions lack this leverage, employers undermine collective bargaining, as they have in Germany.

Furthermore, employers' views do not fall along the lines predicted by institutional theory. Employer associations in all our cases defend national regulation, but in none of our cases is the construction industry as a whole mounting a concerted defense of national specificities. Because employer associations are more national in focus than many large firms and their 
subcontracting networks, they seek an uneasy compromise between the contradictory goals of cheap labor and fair competition. As a result, their positions are inconsistent. In Finland and in Germany, they have demanded regulation to protect their members from unfair or illegal competition, while at the same time opposing enforcement measures that might cost their members money. The main contractors are the key players, and they continue to use transnational subcontracting, while opposing costly social protections. In both Finland and Germany, they have opposed main contractor liability.

Germany, which is usually characterized as having strong, encompassing industrial relations institutions, is facing clear trends toward disorganization. German unions are not just responding to international market pressures. They are also dealing with market making, driven by domestic politics, in nontrading sectors such as health care and telecommunications..$^{90}$ Industrial relations in construction have been radically altered through the transnationalization of labor sourcing, making the worker-friendly aspects of "the German model" a thing of the past. Although actors continue to pay lip service to notions of social partnership, the classic coordination mechanisms, collective bargaining and highly unionized works councils are declining in importance. Lacking the ability to enforce collective agreements on work sites independently, IG BAU has turned to the state for legal enactment of minimum wages and enforcement and-largely out of desperation- has established a migrant organizing project with transnational aspirations. None of this has stemmed decline and disorganization.

Another problem with the institutionalist narrative is the reason for stability in Finland. Most of the literature stresses harmonious labor relations in 
"coordinated" economies, with employers as well as unions supporting CME institutions. On Finnish construction sites, labor militancy is the central mechanism maintaining collective agreements. While the Finnish union in principle has institutional support in the legal extension of collective agreements, this is a reflection of union strength rather than the cause of it. In effect, Finnish institutions regularize and regulate autonomous union action that would probably happen anyway rather than providing effective monitoring of migrant conditions in their own right. This marks Finland off from the other two countries: unlike Britain, CBAs are respected largely due to union control (although the strike threat in the United Kingdom probably does influence employer behavior); unlike in Germany, controls are effective because the union has an autonomous ability to enforce them.

In an increasingly transnational sector, European construction unions have been largely ineffective at including migrants. The only really effective strategy we find for labor market regulation in Finland relies heavily on the worksite-based secondary industrial action of the union's native members. Unlike in Finland, British unions depend on spontaneous, small-scale primary actions by both native and migrant workers. So far, however, they have not been able to build on this tradition of work site-based action because of legal constraints and organizational weakness. Although workplace-centered strategies bring unions to engage more with migrants, it is beyond the unions' resources to do this systematically. Even in settings such as Cottam, where the unions have successfully mobilized, sustained gains among migrants remain elusive, since employers rotate their workforces between countries, that is, outside of a 
national union's jurisdiction.

A logical adaptation to worker mobility would be to establish a Europeanlevel construction workers' union. Only the most beleaguered union in our sample, IG BAU, appears to take this idea seriously. EMWU is well integrated into the daily local-level union work of maintaining national standards and providing services to workers, including migrants. For IG BAU, this is an important step, because it helps to overcome the language barrier and develop knowledge within the organization about the particular problems faced by migrants. However, the long-term significance of EMWU depends on whether other national unions in the EU choose to back it and to allow it to operate in their national territories. All of the unions we looked at recognized the difficulties in organizing and representing workers who move frequently between countries. Unfortunately, except for the EMWU's supporters in the German unions, unionists have not latched onto transnational unionism as a solution. As a result, the EMWU shows few signs of fulfilling its potential of becoming a transnational trade union adapted to the needs of a workforce commuting across national borders. The unions in the country that appears to host the largest number of migrant construction workers, the United Kingdom, are the most categorical in their rejection. Without truly transnational unionism, unions will remain on the permanent defensive, however, depending on swings in the market, their ability to mobilize against neoliberal EU initiatives and their ability to conduct localized industrial actions in defense of national standards.

\section{CONCLUSION}

With the decline of national-level class compromises, national industrial 
relations institutions no longer perform the function comparative institutionalists ascribe to them: they do not channel capital and labor into particular patterns of behavior based on national comparative advantage. Instead, the European construction labor market is shaped by production structure, union and employer interactions, immigration and other policies of various governments, and EU regulatory requirements. Within a particular national context, only the national parts of these dynamics are visible so that for nationally bounded research designs, influences from outside the national context appear as exogenous pressure. Our multilevel research design allows us to see that national trajectories are interrelated, and bound up with European-level developments. It also shows us how the development of transnational labor markets occurs through unions and employers formulating new rules as they go along and creating new precedents in action. As Lillie and Martinez Lucio argue, "Transnational relationships of subnational actors have become so intertwined that it is difficult to understand the strategies of actors within one country without reference to events and actors in other countries." 91 As actors shift among national settings and draw on rules and resources from supranational contexts, new configurations of interest and balances of power emerge, in ways that nationally bounded institutional analysis finds difficult to predict and understand. For these reasons, it is increasingly important to use a more open and actor-centered approach, which can better account for often unclear and shifting transnational and multilevel linkages.

\section{NOTES}

1. Harry Katz and Owen Darbishire, Converging Divergences: Worldwide 
Changes in Employment Systems (Ithaca, NY: Cornell University Press, 1999).

2. See, for example, the contributions of Peter Hall and David Soskice, eds., Varieties of Capitalism: The Institutional Foundations of Comparative Advantage (Oxford, UK: Oxford University Press, 2001); and Wolfgang Streeck and Kathleen Thelen, eds., Beyond Continuity: Institutional Change in Advanced Political Economies (Oxford, UK: Oxford University Press, 2005).

3. Franz Traxler and Birgit Woitech, "Transnational Investment and National Labour Market Regimes: A Case of "Regime Shopping'?" European Journal of Industrial Relations 6, no. 2 (2000): 141-59.

4. Georg Menz, Varieties of Capitalism and Europeanization: National Response Strategies to the Single European Market (Oxford, UK: Oxford University Press, 2005).

5. We borrow the term "autonomous union capacity" from Marcus Kahmann, "The Posting of Workers in the German Construction Industry," Transfer 12, no. 2 (2006): 6, who defines union autonomy as relating to a union's relations "between its members, with non-members and other union organisations."

6. A study by the Confederation of Finnish Employers in 2006 put the number at just over 15,000 but included only those on member company sites, interview with Tapio Kari, labor market director, and Kim Kaskiaro of the Finnish Construction Industry Federation, August 31, 2006. A 2005 Rakennusliitto survey of shop stewards in the Helsinki region estimated 20.7 percent of workers are foreign.

7. Kahmann, "The Posting of Workers in the German Construction Industry," 
185.

8. In Finland, the Rakennusliitto represents all blue-collar crafts directly involved in construction. Other unions cover other staff.

9. These acronyms mean Industriegewerkschaft Bauen-Agrar-Umwelt; Union of Construction Allied Trades and Technicians, and the Transport and General Workers Union. Rakennusliitto, Amicus and GMB are not acronyms. TGWU and Amicus are currently merging as Unite, which is also not an acronym.

10. The relationship between unemployment insurance and union membership has been weakened by the growth of a nonunion unemployment fund, causing a decline in union membership after the depression of the 1990s. Petri Bockerman and Roope Uusitalo, "Erosion of the Ghent System and Union Membership Decline: Lessons from Finland," British Journal of Industrial Relations 44, no. 2 (2006): 283-303.

11. Bernhard Ebbinghaus, "Hoffnung ist nicht genug," Die Mitbestimmung, no. 1/2 (2005): 22-25.

12. Heidi Grainger and Heather Holt, Trade Union Membership 2004 (London: Department of Trade and Industry, 2005).

13. Construction confederation Web site: http://www.thecc.org.uk/index.asp? page =howyoucan (accessed on July 2, 2007).

14. Menz, Varieties of Capitalism and Europeanization.

15. Wolfgang Streeck, "The Internationalization of Industrial Relations in 
Europe: Prospects and Problems," Politics \& Society 26, no. 4 (1998): 429-59.

16. Uwe Hunger, "Globalisierung auf dem Bau," Leviathan: Zeitschrift fur Sozialwissenschaft, no. 1 (2001): 70-82. For other cases of how labor migrations isolate workers and create new forms of control and exploitation, see Ligaya Lindio-McGovern, "Alienation and Labor Export in the Context of Globalization: Filipino Migrant Domestic Workers in Taiwan and Hong Kong," Critical Asian Studies 36, no. 2, (2004): 217-38, on domestic workers, or Nathan Lillie, "Union Networks and Global Unionism in Maritime Shipping," Relations Industrielles/Industrial Relations 60, no. 1 (2005): 88-111, on seafarers.

17. Kathleen Thelen, How Institutions Evolve: The Political Economy of Skills in Germany, Britain, the United States and Japan (Cambridge, UK: Cambridge University Press, 2005), 3; and John Dunlop, Industrial Relations Systems (Boston: Harvard Business School Press, 1992).

18. Hall and Soskice, Varieties of Capitalism, and especially Kathleen Thelen, "Varieties of Labor Politics," 71-72.

19. Kathleen Thelen and Christa van Wijnbergen, "The Paradox of Globalization: Labor Relations in Germany and Beyond," Comparative Political Studies 36, no. 8 (2003): 859-80.

20. Streeck and Thelen, Beyond Continuity, 33.

21. Menz, Varieties of Capitalism and Europeanization.

22. Martin Behrens, Kerstin Hamman, and Richard Hurd, "Conceptualizing Labour Union Revitalization," in C. Frege and J. Kelly, eds., Varieties of Unionism: 
Strategies for Union Revitalization in a Globalizing Economy (Oxford: Oxford University Press, 2004), 11-30.

23. Carola Frege and John Kelly, "Union Revitalization Strategies in Comparative Perspective," European Journal of Industrial Relations 9, no. 1 (2003): 7-24.

24. Jamie Gough, "Changing Scale as Changing Class Relations: Variety and Contradiction in the Politics of Scale," Political Geography 23, no. 2 (2004): 185211.

25. Andrew Herod, Organizing the Landscape: Geographical Perspectives on Labor Unionism (Minneapolis: University of Minnesota Press, 1998); and Mark Anner, Ian Greer, Marco Hauptmeier, Nathan Lillie, and Nik Winchester, "The Industrial Determinants of Transnational Solidarity: Global Inter-Union Politics in Three Sectors," European Journal of Industrial Relations 12, no. 1 (2006): 7-27.

26. Susan Strange, The Retreat of the State: The Diffusion of Power in the World Economy (Cambridge, UK: Cambridge University Press, 1996).

27. Alec Stone Sweet, The Judicial Construction of Europe (Oxford, UK: Oxford University Press, 2004).

28. Menz, Varieties of Capitalism and Europeanization.

29. Lisbet Hooghe and Gary Marks, Multi-level Governance and European Integration (Oxford, UK: Rowman and Littlefield, 2002), 119-42.

30. Trade union interviewees in Brussels all mentioned the insularity of the Commission, whereas employer organization interviewees all said they had good 
access to the Commission when asked.

31. See, for example, Peter Turnbull, "The War on Europe's Waterfront: Repertoires of Power in the Port Transport Industry," British Journal of Industrial Relations 44, no. 2 (2006): 305-26, on the European dockworkers' campaign against the Port Services Directive, which would have undermined collective bargaining in ports.

32. Cyprus, Czech Republic, Estonia, Hungary, Latvia, Lithuania, Malta, Poland, Slovakia, and Slovenia all joined the European Union (EU) at that time. Bulgaria and Romania joined in 2007.

33. This treatment is, however, restricted to certain defined aspects of employment conditions, although the list of conditions that may be regulated is relatively comprehensive. Ulla Liukkunen, The Role of Mandatory Rules in International Labour Law: A Comparative Study in the Conflict of Laws. (Helsinki, Finland: Talentum, 2004): 181.

34. Interview with Oliver Zander, Hauptverband der Deutschen Bauindustrie, March 12, 2007.

35. Jan Cremers and Peter Donders, The Free Movement of Workers in the European Union, CLR Studies 4, (Reed Business Information, The Hague, Netherlands, 2004).

36. Transition periods applied to the eight (now ten) eastern European entrants but not to the two new Mediterranean members.

37. Presentation by Ulla Liukkunen, "The Proposed Services Directive and New 
Challenges for Posted Workers' Regulation in the EU," at the University of Tampere, Finland, May 16, 2006.

38. If the European Court of Justice were to rule that horizontal direct effect (i.e., between private actors) applies to EU law in such cases and that free movement of services takes precedence over labor's right to collective action, then unions might be very restricted in their ability to conduct industrial action (interview with Brian Bercussen, legal advisor to the International Transport Workers Federation on the Viking Rosella case and professor of law at Kings College, London, January 19, 2007).

39. Ralf Michaels, "EU Law as Private International Law: Re-conceptualizing the Country-of-Origin Principle as Vested Rights Theory," Legal Studies Research Paper Series, no. 122, Duke University Law School, Durham, North Carolina, August 2006.

40. The flag of convenience system allows ship owners to place their ships outside the effective jurisdiction of governments and unions through registering their vessels in countries with weak regulatory regimes. Early versions of the Services Directive would have used the country of origin principle to exploit a certain interpretation of the principle of state sovereignty to place employment relations outside effective regulation. Nathan Lillie, A Global Union for Global Workers: Collective Bargaining and Regulatory Politics in Maritime Shipping (New York: Routledge, 2006).

41. Kyosti Suokas, vice chairman of the Rakennusliitto, for example, gave a talk about the directive at a union demonstration in Helsinki in September 2006. The 
Rakennusliitto Web site and members' newsletter make frequent reference to the directive. Finnish employers' groups also discussed the issue for their members; interview with Kari and Kaskiaro, August 31, 2006.

42. European Federation of Building and Woodworkers-European Construction Industry Federation (EFBWW-FIEC) second joint statement, November 9 , 2004, http:// ec.europa .eu/employment_social/social_dialogue/docs/205_20041109 _construction_en.pdf (accessed September 10, 2006).

43. Interview with Laetitia Passot, Social Commission rapporteur; Ulrich Paetzold, director general; and Domenico Campogrande, Economic and Legal Commission rapporteur, of the FIEC, January 14, 2006.

44. Interview with Kari and Kaskiaro, August 31, 2006; interview with Alex Meickle (British) Electrical Contractors Association, September 7, 2006.

45. Council of the European Union, COMMON POSITION adopted by the Council with a view to adoption of a Directive of the European Parliament and of the Council on services in the internal market. 10003/06. (Brussels, Belgium: Council of the European Union, 2006) http://register.consilium.europa.eu/pdf/en/06/st10/st10003.en06.pdf (accessed on September 10, 2006).

46. Interview with Kyosti Suokas, vice chairman, Rakennusliitto, August 30, 2006.

47. Akhlaq Ahmad, Getting a Job in Finland: The Social Networks of Immigrants from the Indian Subcontinent in the Helsinki Metropolitan Labour 
Market (PhD diss., University of Helsinki, Department of Sociology, 2005). http://www.ethesis.helsinki.fi/ julkaisut/ val/sosio/vk/ahmad/gettinga.pdf (accessed on August 15, 2006).

48. Leena Korja-Kaskimaki, “Kiinalaisten kivityontekijoiden lakko voi seisauttaa Taidemuseon tyomaan," Turun Sanomat (September 27, 2003); and Lasse Kerkela and Kaja Kunnas, "Saarretun virolaisyrityksen omistaa usein suomalainen rakennusyrittaja," Helsingin Sanomat (December 5, 2004), for example.

49. In any case, unions are free to bargain higher than the income agreement if they feel they can get more.

50. Jari Hellsten, Study on the Posting Directive: National Report of Finland (Brussels, Belgium: EFBWW, 2004). Although there are reliable statistics on the numbers of work permits granted, there are no such figures for worker posting at the time of this writing.

51. Interview with Vilppu Oikarinen, December 12, 2005.

52. Interview with Riitta Warn, senior advisor, Confederation of Finnish Industries, May 11, 2006.

53. Interview with Kyosti Suokas, August 30, 2006.

54. Boycotts are listed on the Rakennusliitto (RL) Web site; the Web address for 2005 boycott listings is https://www.rakennusliitto.fi/@Bin/46845/Saartotaulukko\%202005 _.pdf (accessed April 30, 2007).

55. Interview with Suokas, August 30, 2006. 
56. Interview with Warn, May 11, 2006.

57. Interview with Toni Andersin, Helsinki Metropolitan Area Industrial Safety District, September 1, 2006.

58. Interview with Kari and Kaskiaro, August 31, 2006.

59. For a full description of these cases, see the Labour Court, judgment 49/05, Case A 268/04, Laval un Partneri Ltd vs. Swedish Building Workers' Union and Swedish Electricians' Union, Stockholm, Sweden; and Aleksi Kuusisto, "Court Upholds Viking's Right to Negotiate with Foreign Unions on Reflagged Ship," European Industrial Relations Observatory (September 6, 2005).

60. Charles Woolfson and Jeffrey Summers, "Labour Mobility in Construction: European Implications of the Laval un Partneri Dispute with Swedish Labour," European Journal of Industrial Relations 12, no. 1 (2006): 49-68.

61. An opinion by an Advocate General is not binding on the European Court of Justice (ECJ) but does indicate the direction the ECJ's decision is likely to take.

62. Interviews with Rakennusliitto officials, May 2005-May 2007.

63. Out of nearly 10,000 e-mail and walk-in "customers" during the Infopoint's first two years, 20 percent were construction workers. Eve Kyntaja, Infopoint director, organizes regular conferences to discuss worker mobility between Finland and Estonia. These are attended by high-level government, employer, and union officials from both countries and attract media attention in Estonia. Eve Kyntaja, "Information Office on Finnish Working Life in Tallinn," Powerpoint presentation (Helsinki, Finland: Suomen Ammatiliittojen Keskusjarjestus [SAK], 
2006).

64. Interview with Ismo Mansikka, regional officer, and Jukka Lindgren, Olkiluoto safety delegate, Rakennusliitto Satakunta office, April 27, 2007.

65. Pyry Lapintie, "Olkiluotoon uusi ulkomaalainen betoniasema," Helsingin Sanomat (August 24, 2006).

66. Pyry Lapintie, "Ydinvoimalatyot paasemassa vauhtiin," Helsingin Sanomat (November 19, 2005).

67. Nils-Eric Backman, "Uuden ydinvoimanlan rakennustyo jaanyt jo pahasti aikataulustaan," Helsingin Sanomat (April 22, 2006).

68. Matti Huuskonen, "Rakennusliitto uhkaa pysayttaa Olkiluodon ydinvoimalatyo- maan," Helsingin Sanomat (November 29, 2005).

69. Interview with Mansikka and Lindgren, April 27, 2007.

70. Kahmann, "The Posting of Workers in the German Construction Industry."

71. Anonymous, Investition, Umsatz und Beschaeftigung im Baugewerbe, Fachserie 4, Reihe 5.2 (Wiesbaden, Germany: Statistisches Bundesamt, 2005).

72. Zentralverband deutsches Baugewerbe, Hintergrund zum Thema Schwarzarbeit und illegale Beschaeftigung (Berlin: ZdB, 2006).

73. Claudia Keller, "Wirtschaft: Schwarzarbeit," Tagesspiegel (June 16, 2002).

74. Kahmann, "The Posting of Workers in the German Construction Industry."

75. One headline in Hamburg screams, "Two Euros an Hour! These are the Slaves of the Construction Mafia," Bild (May 12, 2001), and similar stories have 
appeared in Stuttgart, Erfurt, Berlin, and elsewhere.

76. The Posted Workers Directive does not make provision for extending wage norms when these are not legally established, so without applicable minimum wages or legally enforceable collective agreements, the directive does nothing by itself to set minimum wage standards.

77. Anonymous, Argumentationspapier des Hauptverbandes der Deutschen Bauindustrie zu den Regelungen der Hauptunternehmerhaftung (Berlin: HDB, 2006).

78. Britta Rehder, Betriebliche BUndnisse fur Arbeit in Deutschland: Mitbestimmung und Flaechentarif im Wandel (Frankfurt am Main: Campus, 2003).

79. In the United Kingdom, construction employers have long used the flexible definition of self-employment in U.K. law to avoid labor regulation and trade unions. In 2001, unions estimated a minimum of 361,000 construction workers labeled as "self-employed." Mark Harvey, Undermining Construction: The Corrosive Effects of False Self-Employment (London: Institute for Employment Rights, 2001).

80. Yolanda Ruiz, "Skills Shortages in Skilled Construction and Metalworking Occupations," Labour Market Trends (Labour Market Division, Office for National Statistics, United Kingdom, 2004).

81. The exception to this involved the drowning deaths of twenty-one Chinese cockle pickers in February 2004 on England's northwest coast. Unionists in construction continually refer to this episode. 
82. Interviews with Tom Kelly, GMB, and Andrew Baldwin, GMB shop steward, Terminal 5, February 22, 2007; and Sylvia Cashman, February 21, 2007, BAA Industrial Relations manager for Terminal 5 construction.

83. Although there is a tradition of shop-floor action, because of Thatcher-era industrial legislation, strikes in the United Kingdom require unions to go through an elaborate process to ensure they will not be held liable and fined. As a result, in many cases, industrial action occurs without union involvement, although the union may then become involved to revolve the dispute.

84. John Schemeld, "All-out Unofficial Strike at Cottam Power Station near Lincoln" June 3, 2006) Indymedia.org.uk (accessed on September 7, 2007); and interview with Amicus official Bernard McAuley, July 22, 2006.

85. For a detailed description and analysis of this project, see lan Fitzgerald, Organizing Migrants in Construction: Experience from the Northeast of England (Newcastle-upon-Tyne: Trade Union Congress, 2006).

86. Interview with Jan Mokrzycki, Federation of Poles in Britain, May 2, 2006.

87. Union of Construction Allied Trades and Technicians (UCATT) press release, October 14, 2003. http://www.ucatt.org.uk/ucatt news03.htm\#nr21 (accessed March 15, 2006).

88. Interview with Alan Ritchie, UCATT general secretary, May 30, 2006.

89. Interviews, U.K. construction employers, December 2006-April 2007.

90. Virginia Doellgast and Ian Greer, "Vertical Disintegration and the Disorganization of German Industrial Relations," British Journal of Industrial 
Relations 45, no. 1 (2007): 55-76; and lan Greer "Social Movement Unionism and the Breakdown of Neocorporatist Industrial Relations: The Case of Hamburg's Hospitals." Presentation at the 22nd EGOS Colloquium, "The Organizing Society," July 6-8, 2006, in Bergen, Norway.

91. Nathan Lillie and Miguel Martinez Lucio, "International Trade Union Revitalization: The Role of National Union Approaches," in C. Frege and J. Kelly, eds., Varieties of Unionism: Strategies for Union Revitalization in a Globalizing Economy (Oxford: Oxford University Press, 2004), 159-80. 